\title{
Approaching Negotiation at the Organizational Level
}

\author{
Adrian Borbély (IESEG School of Management) \& Andrea Caputo (University of Lincoln) \\ Peer-reviewed accepted version forthcoming in Negotiation and Conflict Management \\ Research
}

\begin{abstract}
How can an organization improve its negotiation skills? The following article aims to answer this question by investigating how, and why, an organization's negotiation capability should be developed. We propose a four-level model, in which the individual level (I) concerns how people interact at the negotiation table; the linkages level (II) concerns how different negotiations impact one another; the infrastructure level (III) concerns how an organization may organize its negotiation functions; and finally, the capability level (IV) concerns how negotiation can be the source of competitive advantage. Our framework opens the path for developing the understanding of this issue by presenting teaching resources and identifying a possible theoretical underpinning. The article also presents a broad research agenda, which offers the basis for future studies to integrate concepts from different fields of research, such as from the management and strategy literature, into the field of negotiation.
\end{abstract}

Keywords: Negotiation, strategy, management, negotiation infrastructure, capability

Adrian Borbély is Assistant Professor in International Negotiations at IESEG School of Management in Paris (France). A lawyer by training, he holds a PhD in Management from ESSEC Business School, France. His initial research focused on the coordination of the legal and operational functions of the firm and its impact on dispute resolution; it shifted toward the links among the fields of negotiation, organizational structure and corporate strategy. He is also an active mediator and consultant in negotiation. He teaches negotiation at the French top public service schools, in business schools, public administration and companies.

Andrea Caputo is Reader in Entrepreneurship at the Lincoln International Business School (UK). He received his PhD in Management from the University of Rome 'Tor Vergata', in Italy. He has also been Visiting Scholar at the University of Queensland Business School, The George Washington School of Business and the University of Pisa. His main research expertise is related to negotiation, decision-making, entrepreneurship and strategic management. He has authored a number of international publications and his work has been presented at international conferences, such as the Academy of Management, the European Academy of Management and the International Association for Conflict Management. He is also an active management consultant and negotiator. 
Approaching Negotiation at the Organizational Level

\section{Introduction $^{1}$}

"Now that I have been trained in negotiation, how do I make my organization better at negotiating?" Those of us who teach negotiation have probably been faced with a question like this one after performing a training intervention with an executive class. The current authors have faced this question often in different contexts, and the conversations that followed mostly pertained to increasing the training of the organization's employees. A few years ago, following the 2014 International Association of Conflict Management (IACM) Annual Conference dinner in Leiden, we found each other discussing this very same issue which we both faced - despite coming from different countries, having different educational backgrounds, and teaching negotiation to different audiences. That year was the start of a research collaboration aiming to provide a better answer to the question above, and to shift the investigation of negotiation from focusing solely on the individual's behavior toward focusing on the organization's behavior.

Most of the literature on negotiation focuses on how individuals negotiate from a behavioral and/or a strategic perspective (e.g., Caputo, 2013; Sharma, Bottom, \& Elfenbein, 2013; Thompson, Wang, \& Gunia, 2010). Hence, the heart of the field of negotiation lies in organizational behavior and focuses on how negotiators navigate their environment through the management of their interpersonal relationships (Lewicki, Saunders, \& Barry, 2014). In parallel, it is sometimes claimed that performance in negotiation may also be assessed from a collective perspective. For example, the success of an organization, be it a business, a nonprofit or a government agency, may be assessed by its ability to regulate, often through a system of negotiations, relationships with key stakeholders (Ackermann \& Eden, 2011;

\footnotetext{
${ }^{1}$ We would like to thank the tremendous job both the editors and the anonymous reviewers did with us on this manuscript. All the comments we received were constructive and all really helped to grow the paper as it is.
} 
Brouthers \& Bamossy, 1997; Freeman, 2010). Therefore, organizational-level performance in negotiation could be defined as the sum of the results drawn from the individual members' negotiations, whether they are internal (management, human resources, social dialogue, operations, etc.) or external (sales, purchasing, lobbying, dispute resolution, etc.). For the purpose of the present article, we define negotiation broadly to include all interpersonal, intergroup and inter-organizational discussion processes aimed at reaching mutually satisfying, freely accepted agreements (Zartman, 1977) both in deal-making and conflict resolution (Kopelman, 2014).

We advocate for a shift in the understanding of negotiation from individual practices to organization-wide routines, policies and institutions. Organizations should have an interest in treating negotiation as a collective activity and should act upon it (Ertel, 1999). As Movius and Susskind (2009) state, "Organizations that look past negotiation as a core capability do so at their own peril" (p. 5). This requires acknowledgment that negotiations are contextdependent; one negotiates differently based on which organization one serves, which position one occupies in said organization and what policies one must adhere to (Greenhalgh \& Lewicki, 2015). In addition to the negotiator's skillset, the organization itself, the way in which it is set up and its overall approach to negotiation may account for some of the results of such negotiations (Ertel, 1999). Quite surprisingly, although practice demands more knowledge on the topic, there are only a few publications on these questions beyond the article by Ertel (1999) and the book authored by Movius and Susskind (2009), two practiceoriented pieces that qualify as professional literature, in the sense that their claims are not backed by empirical data.

To effectively answer the call for papers on the nexus of negotiation theory, research, teaching and practice, we decided to structure this article to reflect the journey we took while investigating how negotiation can be considered an organizational capability in terms of 
research, teaching, theory and practice. We began working on an organization-wide, systemic approach to negotiation, initially to respond to the practical issue submitted to us. After clarifying our multilevel approach, we will show the pedagogical methods we have developed to respond to the issue. As we quickly encountered limitations with the available theory, which was widely scattered, we will finish by designing an agenda for future research.

\section{The Practical Issue of the Negotiator and His Direct Environment}

Managers are regularly confronted with the issue of the performance of their unit on negotiation and/or conflict management. Not only is a large part of every manager's work dedicated to such tasks (Lax \& Sebenius, 1986), but their team members are also frequently engulfed in negotiations or conflicts of their own, triggering the need for managers to assess their subordinates' negotiations as part of their performance. This is the case, obviously, for sales managers and human resource managers, but, in line with our inclusive definition of negotiation, we claim this should also be the case for anyone in a management or leadership position. Even when staff members do not formally have negotiation responsibilities on their job description, the way they interact with their colleagues or clients may also be looked at from angles such as team spirit, corporate citizenship, relationship-building, and participation, all mechanisms which we qualify, under our definition, as negotiation.

People interested in negotiation will usually first come to receive training. In doing so, they often discover a world of new concepts, frameworks and ideas that usually excite them. Their objective is to increase their personal efficiency at interacting with their key stakeholders, who are sometimes their own team members. Although the long-term impact of such training is still questioned in academia (ElShenawy, 2010), it is undeniable that participants' satisfaction with these sessions is usually very high (Movius, 2008). This leads participants to raise the question of "What's next?" The two most obvious responses are either 
to suggest that they take advanced courses on the topic, or that they advocate for their colleagues and subordinates to partake in similar training programs. These are comfortable answers, as they guarantee our schools more teaching assignments (i.e. more revenue), while also letting us stay in our habitual, easy-to-control teacher-student interactions.

Over time, we have grown less and less satisfied with these answers. It is clear that negotiators do not operate in a vacuum; they are influenced by their environment, especially the immediate environment of their own organizations (Bottom \& Studt, 1993; Thompson \& Loewenstein, 1992; Walton \& McKersie, 1965). Organizations want to drive and control employees' behavior, something which is particularly difficult when it comes to complex human activities such as negotiation (Borbély, 2011). Such control can be maintained in commercial activities; for instance, salespeople and purchasing specialists deal with extensive reporting duties, and their remuneration schemes and career paths are closely related to their performance. Together with training and on-site coaching, organizations want to ensure they are best served by their trade negotiators (e.g., Johnston \& Marshall, 2016). In addition to an evaluation based on gross sales or margin, key account managers may also be incentivized based on the quality of their relationships with key suppliers and/or customers (e.g., Sengupta, Krapfel, \& Pusateri, 1997). To our knowledge, beyond being utilized in sales and purchasing, such practices are rarely expanded to other positions involving negotiation, such as lawyers, or functional and general managers. For example, in-house legal counsels are rarely given clear, systematic objectives when it comes to negotiating pre-dispute and contentious situations (Borbély, 2011). Of course, non-trade staff members may be instructed to act one way or another, yet they rarely have negotiation-related key performance indicators applied to all their cases. Linked with their performance appraisal, such KPIs may help raise awareness of what exactly is expected from them, to better fit negotiation behavior which is aligned with the organization's strategy, and thus drive their behavior. Conversely, although managers 
spend a lot of time negotiating when dealing with a team or project, they are generally left free, and alone, to deal with the different negotiation and conflict situations they may face.

This, therefore, raises the question of necessary complements to one's negotiation skills, especially from an organizational perspective. Is the organization helping or hindering negotiation efforts? Is it effective at driving negotiators' behavior so that they deliver what their hierarchy expects from them? Our goal here is not to limit our discussion to the management of negotiators; as we will explore, there are positive actions an organization may take to support their negotiators' daily actions (such as coaching) and otherwise assist negotiators in their tasks. In other words, a key question to address is whether the organization is aware of its negotiation potential, and if this potential being enabled.

Taking a consulting approach toward the issue, Danny Ertel was the first, to our knowledge, to raise the question of organizational-level management of negotiation activities. In a 1999 Harvard Business Review article, he describes examples of possible interventions for improving the negotiation skills of functional teams (Ertel, 1999). He draws examples and counter-examples from different fields, from loan management to alliance negotiating teams and newspaper advertisement space sales. He suggests negotiators may be more effective if supported by a series of measures such as knowledge management (databases of negotiations and good practices), informal exchanges of practices among staff members (including mentoring by senior negotiators) and the installment of better negotiation processes (preparation, reporting, etc.). His management inferences are closely related to key points of the joint gains negotiation method (Fisher, Ury, \& Patton, 1981). For example, he advocates for the use of performance indicators in addition to the financial aspects of a deal (relationship, negotiation efficiency, value-creation, etc.). At no point does Ertel suggest that negotiation should be standardized around strict checklists, to be applied by robotic individuals. On the contrary, we think his prescriptions could enrich the job of negotiators 
across the organization by assessing them through the lens of a wider set of performance indicators, which could, for example, take into account moves at the table, non-financial outcomes, relationship management, etc. (Ertel, 1999).

Ertel's examples of success are mostly sectorial, in the sense that they demonstrated how one unit, or function of the firm, increased its performance through updated negotiation practices. This leads one to ask how this could be achieved across the board; i.e., how good practices may be expanded from one successful function of the firm (say: purchasing) to others (e.g., the law or HR department). Ertel also implies that the good practices he advocates could impact positively on the performance of the organization as a whole, without assessing it quantitatively or demonstrating the exact way such a correlation may operate. Ertel has the advantage of putting the idea out there, but he has clearly not done so in a scientific manner.

Making a team or an organization better at negotiating may therefore be done through two complementary ways. First, as Ertel (1999) and Movius and Susskind (2009) suggest, positive actions may help individuals perform better with negotiation. Second, seeing negotiation as a value-creating intellectual activity leads one to assume that some control mechanisms must be developed in order to ensure that negotiators deliver on their responsibilities (Sharma, 1997). The combination of positive reinforcement and management control constitute what we will later call a "negotiation infrastructure".

Such a practical issue requires combining a management approach, (i.e., a good understanding of how organizations function), with a thorough understanding of negotiation, both in theory and in its multiple possible contexts of application. In other words, it may pave the way for the emergence of "negotiation consultants," a rare species at this point. In their search for better efficiency, and at the same time better places to work (negotiation and 
conflict management are often at the heart of "happiness at work" strategies - e.g., Costa, Passos, \& Bakker, 2015), practitioners are calling for a better understanding of such issues.

\section{A Model to Approach Negotiations from an Organizational Perspective}

In order to organize our discourse, we propose that negotiation may be approached from four complementary lenses, depending on the breadth of perspective one wishes to take. These are not well-defined categories, but different viewpoints of the same object, depending on the perspective and the distance one wants to take. We do not claim that these lenses are new; we consider our contribution to be in consolidating them into a single framework. These varying lenses are drawn from our observation of the real world and shall be linked to different theoretical disciplines and concepts. Our model is not solely based on scientific literature but also practice and the professional literature. We are aware that we face the risk of being considered not to be rigorous enough, however we believe this approach to be necessary (due to the absence of scientific literature that tested Ertel's (1999) ideas), and innovative, as we are not considering negotiation with the exclusive lenses of theory but we are bridging the gap with "real world" issues. Indeed, negotiation is not only a science, but also an art, which heavily relies on practices and experiences (e.g., Raiffa, 1982). These lenses are presented in Figure 1 below.

\section{[ INSERT FIGURE 1 HERE ]}

Level I is the classical, organizational-behavior approach, which focuses on the human interactions at and around one negotiation table at a time. It is about how people interact within the frame of one negotiation. Looking at recent literature reviews of the field (e.g. 
Thompson et al., 2010) or pivotal books (e.g., Lewicki et al., 2014; Olekalns \& Adair, 2013), this level encompasses most of the scientific work in the field of negotiation to date.

Level II, the next broadest approach, suggests that negotiations do not happen in a vacuum, but rather that different negotiations necessarily impact on one another. Crump (2010) suggests looking at negotiations as being embedded with other negotiations through various forms of "linkages," defined as "the way in which one discrete negotiation influences or determines the process or outcome of another" (Crump, 2010, p. 3). His examples include a current negotiation with a historical supplier, which heavily depends on past negotiations (past dependency) and on current negotiations with competitors (also known as Best Alternative to the Negotiated Agreement, or BATNA). Similarly, each negotiator may be involved in internal negotiations of their own, either because they negotiate within a team (e.g., Behfar, Friedman, \& Brett, 2016), or in their relationships to their principals (e.g., Lax \& Sebenius, 2006; Mnookin \& Susskind, 1999). Level II underlines the idea that some negotiations serve as the context-- the background-- for other negotiations; this is just a first step in the direction of our claims and, from this point on, we will be focusing our discussion on the next two levels.

Level III deals with management, i.e., how a negotiation function is driven so that each one of its members act in a way that serves the whole community. In other words, how does the organization handle the agency problem across all negotiations? The agency issue is here taken from the principal's perspective: as agents negotiate, their hierarchy needs to do everything they can to ensure that negotiators deliver what they expect. Negotiators need to be properly hired, trained, coached, incentivized and monitored, all of which are issues related to Human Resources, and when it comes to managing salespeople, this is the domain of Sales Management (Johnston \& Marshall, 2016). In an ideal world, all negotiation activities, not just sales and purchasing, would be subject to some form of management and control (Ertel, 
1999). Control of negotiation activities is made difficult not only due to the asymmetry of information, but also due to the asymmetry of knowledge which hinders the manager's ability to assess what the agent is doing (Borbély, 2011). Beginning with the practical insights of Ertel (1999) and Movius and Susskind (2009), there are multiple changes of multiple natures that can make negotiators more efficient as a community; this is what we call "building a negotiation infrastructure." Moreover, by building such a negotiation infrastructure, focused on fostering communication and learning across the organization, organizations may develop an enhanced corporate negotiation culture which would in turn help in supporting more effective and efficient negotiations.

Level IV adopts an even more distant standpoint to offer an approach to negotiation from a strategic perspective. Here, "strategy" is not used to refer to the choice of strategy to be used at a negotiation table (e.g. cooperative vs. competitive). Rather, we are referring to the strategy of the organization, which includes its positioning on the market, its perspective in doing business, how its plans are conceived and implemented, its tactics or ploys, and, finally, its pattern of actions (Mintzberg, 1987). Here, we postulate that negotiation should be considered an issue of the utmost importance at the highest levels of the organization, as it is central for managing relationships with the main organizational stakeholders. Hence, in line with the vocabulary used in the management literature, we talk of negotiation as a "capability," i.e. an element of potential differentiation for the organization to reach competitive advantage (e.g., Collis, 1994), a term which we will elaborate on in the theory section. As negotiation affects how strategic choices are made (Amason, 1996; Kauer, Tanja, \& Utz, 2007) and implemented, for example, with social dialogue (e.g., Munduate, Euwema, \& Elgoibar, 2012), we postulate that organizations with better negotiation practices will have strategies that prove to be not only more successful but also, in all likelihood, more innovative as well. We propose that negotiation, built as an organizational capability, can play a major 
role in contributing to the strategic success of the organization, and can also provide it with an advantage over its competition. Organizations should therefore develop strong capabilities in negotiation if they want to succeed. In the pedagogy section, we will discuss the example of an airline which appears to have developed such a capability and placed it at the heart of its performance in the air travel market.

\section{[ INSERT TABLE 1 HERE ]}

Our model invites practitioners to look at negotiation from high above and integrate both the strategic and managerial aspects of negotiation in order to make organizations more efficient at negotiating and managing their key stakeholder relationships. One may make individual negotiations more efficient within an organization by recognizing firstly that negotiations are linked with one another (level II), secondly that there are management levers that can be activated (level III), and finally that this requires negotiation to be considered as a useful capability at strategic level (level IV). These reflections call for a renewed approach to pedagogy, theory and research in regard to negotiation within organizations, as we will detail in the following three sections.

\section{Teaching "Organizations as Negotiators"}

While identifying a practical issue and gaining some clarity about negotiation is one thing, teaching it is another, especially considering the limited literature on the topic (Greenhalgh \& Lewicki, 2015); in this case, it required drafting specific pedagogical tools.

Considering the practitioners' expectations, we added a layer of management and corporate strategy to our teaching of negotiation, which initially focused only on individual interactions (level I and, incidentally, level II). We do not claim one should replace the other, 
especially at the basic level, but rather that both may complement each other at a more advanced level, especially with graduate students who have had previous initial training on negotiation. At one of the authors' schools, a series of initiatives was taken with students majoring in business negotiation within a specific module entitled "Negotiation, Strategy and Company Observation," ${ }^{, 2}$ elements of which both authors now teach widely, especially at executive level. These initiatives mainly call for students to acknowledge three ideas.

Idea \#1 is that strategy impacts negotiation (level IV). The way in which one negotiates depends on the strategic variables of the organization one serves, as such variables can be considered as frames influencing (or biasing) negotiators (Bottom \& Studt, 1993). Proper training in negotiation should therefore include learning how to read corporate strategy from a negotiation perspective; in other words, strategic analysis tools may provide interesting insights for negotiators. For example, Porter's five forces show where an organization's most intricate, unbalanced negotiations may be found, whether these are with its suppliers, customers, or current and future competitors (Porter, 1979). SWOT analysis (Strengths Weaknesses Opportunities Threats), when used for both parties at the table, enables the isolation of trade-offs, e.g., between one's strengths and the other's threatening factors. Cost-benefit analysis, often used for strategic choice, may also be used to assess a proposed deal. Strategic analysis, therefore, offers multiple tools that can help different parties to identify interests in their negotiations. Beyond this, a negotiator will face a different negotiation equation, depending on who he negotiates for. It goes without saying that a purchaser for Wal-Mart does not negotiate the same way as his equivalent at the local food co-op, even if they may negotiate the same things with the same counterparts.

\footnotetext{
${ }^{2}$ We must acknowledge the contribution of Prof. Ian Speakman, currently affiliated with the Cranfield School of Management in the UK, for the original idea and creation of this course modules, as well as Prof. Jimena Ramirez's, from IESEG School of Management, for her involvement in updating and running the course these past years.
} 
Idea \#2 is that the success of an organization's strategy depends on the success of its negotiations across the board (level III and IV). After all, strategy definition is usually the result of many dialogues and debates within the organization, or at least within its topmanagement team (Dye \& Sibony, 2007). Strategy implementation also depends on one's ability to buy-in internal and external stakeholders, oftentimes through negotiation with unions, key suppliers and customers, majority shareholders and/or the associated regulation authority (Brouthers \& Bamossy, 1997). The decision-making culture of an organization and its impact on social dialogue and everyday management negotiations may play a role in the creation and successful implementation of its strategy.

There are therefore points of contact between negotiation and strategy. Between these two levels lies management (level III). Idea \#3 aims to teach students frameworks for ensuring that everyone within the organization negotiates to their full potential and in alignment with the organization's strategy. Available tools include teambuilding, training and coaching policies, setting up the right incentives and managing in a way that conveys priorities to everyone around (leadership). Some initiatives may be local, for example a company may train their litigation team in dispute negotiation in order to avoid litigation whenever possible; others may be shared across several functions of the organization (e.g. purchasing together with sales), or may be done through an organization-wide negotiation “infrastructure." Here, as there are no overarching frameworks covering the management of negotiators, and because of the diversity of practices among organizations, we rely mostly on a case study pedagogy.

To support such learning points, one may find only a few tools, the first of which is adopting Ertel (1999) as compulsory reading for students. Using case studies in class is also advocated. First and foremost, students can easily grasp the negotiations practiced at their university, so we often use their school as an example. One of our schools is currently 
constructing a new building on its secondary campus, which is in line with two strategic elements: a "best place to work" strategy for employees, as well as a new balance among campuses. This has required a series of negotiations, especially with the staff, regarding office allocation and other aspects of everyday life, and it has also led to significant amounts of conflict and negotiation that not only affect the campus, but also the cross-campus relationships. This is an example of how a strategic choice impacts managerial and HR negotiations and should call for efficient dialogue mechanisms.

We also propose using full-fledged business case studies. One particularly interesting study deals with Ryanair, the Irish low-cost airline (Borbély, 2014). This company uses a coherent, dominating approach toward all its stakeholders, including those which should be more powerful than them, thus drawing a significant part of their yearly profit from their negotiations, as opposed to their flight operations. The company, one of the largest European airlines, and among the rare airlines which are profitable, imposes their take-it-or-leave-it negotiation style on employees (few airlines currently recruit) and their passengers (who pay the bare minimum for minimal service). In theory, airlines suffer from a lack of power toward some of their suppliers, especially aircraft manufacturers and airport operators (Porter, 2008). Ryanair has shown that it possesses the ability to reverse these power asymmetries by applying their signature negotiation approach to these all-powerful stakeholders, imposing their conditions on Boeing (mainly by choosing when to make deals with them) and with airports (by selecting secondary platforms eager for service). This case serves to teach students how a dominant strategic position on the market can sustain certain negotiation practices (and vice versa, as it is possible that their negotiation practices have actually contributed to them reaching the dominant position which they occupy on the market). Discussion points enable the linking of negotiation theories to corporate strategy, business economics, public relations and ethics (Borbély, 2014). 
Perhaps an even more interesting feature of the Negotiation, Strategy and Company Observation module lies in the "Company Observation" component. Students, in groups, are required to interview practitioners on issues linked with the course topics, in order to integrate their understanding of theory with practice. Students choose their research question and target organizations; they are coached by their instructor, who helps them critically discuss their data and bridge it with diverse literature (in negotiation and beyond). These assignments have led to very insightful learning points; below are a few examples that have been gathered throughout the years.

One group was interested in how a three-person start-up company in digital marketing handles their huge, Fortune 500 multinational clients. They were expecting a very unfavorable imbalance in power but discovered that the small company does not negotiate with its large clients; as their service is highly innovative, and almost unique to the market, they simply impose their conditions on their big clients. This led them to conclude that, because of the innovative strategic positioning of their company, negotiators can reverse the power balance at the table.

Another group is currently investigating how professionals from different countries are impacted in their external negotiations by the image their company projects and what these companies could do, at a strategic level, to make their negotiations easier. They may unveil mechanisms through which image management (mostly marketing but also corporate social responsibility) impacts negotiations, with possible differences across cultures.

Yet another group looked at a new company similar to Groupon, which was positioned as an intermediary between service providers and consumers. Such companies live off the deals they negotiate with shop owners for their customers. Here, negotiations proved very difficult, because of the failing strategy of the company, the students concluded. From their 
negotiation practices, they were therefore able to identify limits to such a B-to-B-to-C business model.

Our last example (there are many more) is a group of students that wanted to look at the specificities of negotiation in companies acting in "controversial sectors", such as gambling, tobacco, alcohol and firearms (Cai, Jo, \& Pan, 2012), thereby linking corporate social responsibility (a strategy issue) with negotiation. They concluded that this required an even more relationship-oriented negotiation approach to external stakeholders, and they could observe that negotiators needed extensive negotiation and legal training, especially because of the sensitive nature of some of the information they deal with.

We acknowledge these learning insights, although very practical, are all but scientific. Most of them could be characterized as "common sense." We are nonetheless able to use such examples to enrich our executive education programs and to respond to the consulting needs of the companies we encounter. Recently, when called to train purchasing agents in a do-ityourself store chain, we incorporated elements of strategy and management into our negotiation training, and we could help participants build varying and tailored tools to support a collaborative approach to their negotiations, in this instance, a knowledge base and a “negotiators" club".

\section{Relevant Theories to Support Organizations as Negotiators}

As we have noted, there is a logical argument based on practice that negotiation and corporate strategy intertwine in two main ways. Both the strategic resources an organization has and the position an organization can exploit impact the way its agents negotiate deals and resolve conflicts (Appelt \& Higgins, 2010; Bottom \& Studt, 1993; L. Thompson \& Loewenstein, 1992). Conversely, for a strategy to be successful, it requires negotiating a network of internal and external stakeholder relationships (Donaldson \& Preston, 1995). 
When Air France proposed to open a low-cost branch across Europe, its inability to get unions onboard with the project had significant strategic consequences (Clark, 2014, September 29). In other words, the negotiation skills of the top management team can significantly impact both the company's strategic design and its implementation. As such, negotiation appears to play a key role in linking intended, emergent and realized strategy. According to Mintzberg (1978), an intended strategy is the strategy that an organization's top management team wishes to execute; an emergent strategy is an unplanned strategy that arises in response to unexpected internal or external conditions; and a realized strategy is the strategy that is actually implemented. As such, there are strategic choices that are intended but never realized, replaced by strategic moves that emerge in a bottom-up, natural manner, without explicit intervention from top management (Mintzberg, 1978; Walsh \& Fahey, 1986). The negotiation abilities of the parties forming the organization therefore would play a major role to explain how and why strategy, whether intended or emergent, is realized.

Despite the establishment of alternative views developed in separate theoretical boxes, from a theoretical standpoint, there appears to be no coherent and systemic approach integrating what we know about negotiation and strategy. This leaves us with questions such as, "To what extent has negotiation been approached from a strategic perspective, and how can this be improved?" or, "Should negotiation be viewed as a corporate capability, and if so, what can its contribution to competitive advantage be?" which are so far unanswered, or at best, partially answered by a scattered set of studies. To begin answering these questions requires covering two distinct streams of literature in search for coherence, a multidisciplinary approach that modern scholars generally tend to avoid.

Looking for crossover from the strategy literature in the negotiation literature brings us to studies that examine conflict within strategy-making teams, its determinants and its consequences on strategy formulation (Amason \& Schweiger, 1997; Elbanna, Ali, \& Dayan, 
2011; Parayitam \& Dooley, 2011). These studies mostly relate to the school of thought that considers strategy as a top-down phenomenon, with leaders defining strategy in formal settings, often behind closed doors. Hence, improving the decision-making process, seen as a negotiation process, of top management teams should improve the overall saliency of strategy within the company. However, this approach, as we have seen, constitutes only one side of the coin. If we read Mintzberg (1978) from a negotiation perspective, we are likely to conclude that dialogue, participation and negotiation practices within the organization in its entirety may have a profound impact on strategy formulation and implementation. Therefore, whether one adheres to the former view of strategy or the latter, negotiation can play a fundamental role in the strategic process, whether it is bottom-up or top-down.

In strategy journals, most of the research approaching negotiation at the organizational level refers to distinct contexts, mostly collaborative forms of strategy such as mergers and acquisitions (Dierickx \& Koza, 1991; Jemison \& Sitkin, 1986; Walsh, 1989), joint ventures (Brouthers \& Bamossy, 1997; Lee, Chen, \& Kao, 1998; Luo, 1999; Luo \& Shenkar, 2002; Yan \& Gray, 2001), and strategic alliances and outsourcing (Lippman \& Rumelt, 2003). For example, Jemison \& Sitkin (1986), while studying the acquisition process as a determinant of acquisition activities and outcomes, argued that the negotiating practices in the acquisition process affect the success of the whole operation. This is particularly true when thinking about the acceptance of the acquisition by the employees, where the lack of support during the transition period tends to result in dissatisfaction and lower productivity (Jemison \& Sitkin, 1986). Moreover, research on acquisitions remains largely controversial regarding the reasons why well-designed acquisition processes fail (Jemison \& Sitkin, 1986). On this account, the strategic fit cannot be considered as the only variable; the process of negotiating the acquisition and integrating the target into the parent company should also be considered as one of the drivers of success (e.g. Dierickx \& Koza, 1991; Jemison \& Sitkin, 1986). 
Further studies link strategic success with internal negotiations between headquarters and subsidiaries (Dörrenbächer \& Gammelgaard, 2006) or external negotiations with governments (Weiss, 1990).

When it comes to the analysis of corporate behavior, most of the strategy literature is grounded on the concept of bargaining power (Porter, 1980). Although a lot has been said on bargaining power from an industrial economics perspective (Kim, 1988; Moatti, Ren, Anand, \& Dussauge, 2014), there has been very limited research into how negotiation differs depending on the power context. As shown, whereas some studies look at specific strategic negotiations, few consider negotiation as a whole from a strategic point of view, which unveils a missing theoretical link between behavioral practices at diverse negotiation tables and how they should be considered at the highest levels of the organization.

Recent works on institutional practices (Helfen \& Sydow, 2013; Helms, Oliver, \& Webb, 2012) can help understand the dimensions of how organizations behave in negotiation situations. Helms et al. (2012) point out how new practices sometimes arise "from the efforts of numerous and diverse organizations working together to negotiate a settlement on a new institutional arrangement (trade associations, for example, working to develop novel industry standards)" (p. 1120). Although it is a common saying that organizations do not negotiate, only individuals do, Sydow, Schreyögg, \& Koch (2009) argue that negotiations within the organization are among the factors that generate self-reinforcing patterns in organizational culture, and how such factors should be considered within a theory of organizational path dependence, intended as a broad label indicating the imprinting effects of the past on the behavior of the organization. This opens the door for the study of negotiation at the organizational level. If we think about unions or institutional organizations, their negotiation strategies will be relatively consistent despite changes in the negotiating team, showing some form of institutional movement behind individual practices. Therefore, an organization's 
strategy may influence its members' negotiation behavior. For example, Pahl \& Roth (1993) show how some key variables in strategy formation may impact conflict-proneness and negotiated relationships between headquarters and foreign subsidiaries. Similarly, other strategic decisions and subsequent negotiations are centralized and produce a structured and idiosyncratic way of negotiating in the organization (Quélin \& Duhamel, 2003).

\section{The Resource-Based View of the Firm and Negotiation as a Capability}

The aforementioned studies are the few relevant examples we could find that address negotiations from a somewhat systematic perspective, rather than as individual exchanges among negotiators. However, there does not seem to be a consistent theoretical framework that aggregates the view on negotiation in the strategy literature. At this point of our argument, we believe it is important to attempt to suggest several theoretical lenses through which negotiation could be investigated as an organizational capability. We propose that the theory emanating from the resource-based view of the firm (RBV), and its subsequent expansion through the concepts of dynamic capabilities of organizations (Teece, Pisano, \& Shuen, 1997), can offer a suitable theoretical framework under which the way in which organizations negotiate could be investigated in a more systematic way.

The RBV theory posits that strategy is about funneling resources and capabilities in order to reach strategic objectives. Contrary to other strategy theories that look at how organizations navigate their external environment, RBV looks at the success factors related to the organization's internal environment, consisting of resources - tangible and intangible and capabilities - the processes through which resources are put into productive motion (Wernerfelt, 1984).

Dynamic capabilities are defined as those capabilities firms use to "integrate, build, and reconfigure internal and external competencies to address rapidly changing 
environments" (Teece et al., 1997, p. 516). Speculating on this, Winter defines an organizational capability as "a high-level routine (or collection of routines) that, together with its implementing input flows, confers upon an organization's management a set of decision options for producing significant outputs of a particular type" (Winter, 2003, p. 991). In their seminal article of 2000, Eisenhardt and Martin claimed that dynamic capabilities actually consist of identifiable and specific routines. Some dynamic capabilities integrate resources, such as product development routines (e.g., Toyota). Strategic decision-making is considered a dynamic capability in which "managers pool their various business, functional, and personal expertise to make the choices that shape the major strategic moves of the firm" (Eisenhardt \& Martin, 2000, p. 1107). Other dynamic capabilities focus on the reconfiguration of resources within the firm, such as transfer processes, resource allocation processes, and synergistic processes. Others are related to retaining and releasing resources, such as knowledge creation or alliance and acquisition capabilities. Emerging from path-dependent histories, which we have seen are influenced by negotiation (Sydow et al., 2009), dynamic capabilities are characterized as unique and idiosyncratic processes, although dynamic capabilities also exhibit common features that are associated with effective processes across firms (Eisenhardt \& Martin, 2000). Thinking back to the example of Ryanair we provided in the teaching section, negotiation could very well be considered as a dynamic capability at the root of the airline's performance.

This has been confirmed in a recent review on alliance capabilities; negotiation may be considered as a firm-level ability within the individual-alliance capability. Individualalliance capability is defined as a firm's ability to search, negotiate, manage, and terminate an individual alliance (Wang \& Rajagopalan, 2015). Negotiation is considered one of the stages of the life cycle of an alliance, specifically the stage at which the terms and structures of the collaborative agreement are negotiated (Simonin, 1999). However, we believe that 
considering negotiation simply a one-off activity which relates to terms and structure of an agreement, without considering the pre- and post-agreement negotiation processes that the firm engages into, is limited and could be developed with further research.

The RBV literature directly links capabilities and performance. In particular, it introduces the notion of "human capital" (Hitt, Biermant, Shimizu, \& Kochhar, 2001). A negotiation take on this concept leads to the idea of "relational capital," defined as "the set of all relationships - market relationships, power relationships and cooperation - established between firms, institutions and people that stem from a strong sense of belonging and a highly developed capacity of cooperation typical of culturally similar people and institutions" (Welbourne \& Pardo-del-Val, 2009, p. 486). Defining the outcomes of successful negotiations as part of the firm's capital shows the importance that negotiation may take and its potential impact on the organization's performance.

Based on these scattered sources, we argue that negotiation can and should be considered a capability at the organizational level, and not only at the individual level. In other words, considering negotiation an organizational capability that requires careful nurturing may be of strategic importance for corporate organizations. Most of the studies investigating negotiation look at a single event or a short series of events, rather than all negotiations that constitute and/or affect the organization at once. While this treatment may be appropriate for investigating unsophisticated transactions in a stable environment, this approach is questionable for complex, long-term endeavors (such as the lifespan of an organization) on unstable environments, such as today's global market where firms compete. According to Teece (2007, p. 1319), “enterprises with strong dynamic capabilities [...] not only adapt to business ecosystems, but also shape them through innovation and through collaboration with other enterprises, entities, and institutions" (p. 1319). 
Theory drawn from the literature on strategy offers a framework for considering negotiation from a strategic point of view. We believe this is the right path towards building negotiation into the processes of the organization at the management's level (the "negotiation infrastructure"). In other words, it could well be that only when negotiation is considered relevant at the top level of the organization (level IV) can the organization act upon it and build the necessary management tools to develop and nurture the negotiation capability (level III). Following the logical argument proposed by Ertel (1999), we propose that negotiation as a capability enables linking collective negotiation efforts with organizational performance, a proposition that is grounded on practical experience, although not yet substantiated in research. Organizations that are stronger at negotiating, not only around one particular negotiator or even as one of its functions (be it sales, law, or employment relations), but across the board, may therefore perform better than their counterparts. These theories (and others) need to be integrated with the negotiation field as we know it, and empirical support needs to be gathered. In the next section we call for an agenda for future research studies to empirically support our framework.

\section{An Agenda for Future Research}

The issues raised in this article have not been the topic of much empirical research so far, especially in literature from the field of negotiation. From our knowledge of the literature, negotiation as a field appears to be mostly concerned with what happens at and around the discussion table (levels I and II of our model), with little, or indirect consideration for broader organizational issues surrounding negotiations (Caputo, 2013; Sharma et al., 2013; Thompson et al., 2010). One may explain this by the gap in perspective and methodology between the traditional, micro-organizational behavior approach, and the more macro-organizational level stance adopted by strategy researchers (Stimec, 2014). A meso approach that would look at 
the interface between the micro and the macro is what we are aiming for. In other words, this requires seeing negotiations as being embedded within their context, particularly the organizational context. This is coherent with Zartman's call for an "integrated" approach to negotiation research (Zartman, 1988), one that focuses on the processes and behaviors, while acknowledging the context at each stage of the negotiation (Stimec, 2014).

This raises methodological challenges and the need to offer a complementary approach to the all-too-prevalent experimental approach to negotiation research (e.g., Greenhalgh \& Lewicki, 2015). Indeed, departing from level I, it appears difficult to reproduce organizational levers in the simplified settings of a lab, unless experiments could be run over a longer timeframe to enable some form of organizational acculturation. Collection of field data appears to be necessary to study the phenomena at play in levels III and IV. It is in this methodological spirit that we propose broad avenues for future research.

First, the strategy literature offers lists of reasons as to why organizations are successful, based on certain elements drawn from their strategy, including position on the market, the innovative nature of their products and services, and agility, which they may draw from small size or relative young age, etc. (Grant, 2010; Mintzberg, Ahlstrand, \& Lampel, 1998). Through which mechanisms these translate into negotiation practices remains largely unclear at this point. Some ideas may be evident: a company which enjoys a dominant position on the market may have the advantage of being able to afford to be more aggressive in their negotiations (much like Ryanair - Borbély, 2014); negotiators, being salespeople or buyers, will negotiate differently based on where the products or services their employer sells stand on the lifecycle curve (Anderson \& Zeithaml, 1984; Rink \& Swan, 1979). The way in which such a translation happens remains quite elusive. Also, is there a contamination effect? For example, to what extent do external negotiations (that may be influenced by strategic factors, such as market dominance) impact the ways internal negotiations take place? What 
factors surrounding negotiators are at play that enable them to internalize their organization's strategy elements, whether they serve as strengths or weaknesses at the negotiation table? Do these strategy elements appear through training, acculturation or just naturally? In other words, what part of the process lands within the negotiation method, and what part has to do with the organization itself?

Conversely, how do organizational negotiations, beyond the top-management team interactions, impact strategy-making? Can we link practices, such as social dialogue, participation mechanisms, or management culture (i.e., how daily negotiations take place), to certain variables in strategy (e.g., ambition, risk-taking, innovation, etc.?) For example, could more people trained in conflict management be linked with more of a bottom-up strategy formulation? When it comes to strategy implementation, we may form an ad-hoc perspective that better negotiations with internal and external stakeholders may translate into easier strategy implementation. To our knowledge, there is not an overarching intellectual framework that explains this correlation and unveils the mechanisms at play.

The approach initiated by Ertel (1999), followed by Movius and Susskind (2009) is experiential. They draw cases from their experience as consultants and infer performance from the good practices they developed. The exact contribution of changes to negotiation methods on performance remains to be assessed. In addition, generalization power appears to be missing. Do companies that take negotiation-related initiatives enjoy more performance, and if so, on which variables? For example, how does a negotiation infrastructure impact not only organizational financial performance but also the personnel's motivation and career development? Another issue worthy of research is the obstacles to such efforts pertaining to negotiation within organizations. In other words, if a negotiation infrastructure leads to increased performance, as the quoted authors imply, why are there so few companies actually 
investing in such an infrastructure? If they are aware of this, is it because they do not hold the right competencies? Or do they simply lack awareness of the issue?

In terms of research, to study the organizational context of negotiation, our suggestion is to reach out to practicing negotiators or experienced managers with inquiries about these phenomena. The traditional experimental approach could be of use when participants are managers or negotiators (e.g., Caputo, 2016); however, we do not believe that using students, who are rather inexperienced, as subjects would be appropriate in such a context. Rather, we think collecting the information we need would require complementing what exists with conducting inquiries with experienced practitioners. Two approaches appear possible. The first includes surveying different organizations and looking at drivers of performance related to negotiation. The second, and probably initially more appropriate approach, would be using certain organizations as case studies; this would enable a more in-depth approach of a limited amount of organizations, and allow for comparisons among organizations. Here, a possible approach would be through action research, a methodology that couples a change consulting approach with pre- or post-scientific evaluation (Bradbury-Huang, 2010; Brydon-Miller, Greenwood, \& Maguire, 2003). In any case, quantitative and qualitative methodologies may be used separately or combined.

\section{Conclusion}

We believe these reflections to be innovative, and also that they bring value to the field of negotiation. We embarked on this research project with many certainties and now have more questions than we started with. We have discovered how practice, teaching and research on negotiation seem to belong to different worlds. As such, our observations are less about developing new concepts and more about importing existing concepts from other fields, namely marketing, management, sales management, leadership, and control, etc., revealing questions that we hope will trigger a reflection in all scholars interested in studying 
negotiations from a more systematic perspective, integrating the rigor of theory with the reality of practice. In particular, we hope to trigger a methodology discussion on how to address the higher levels of our model, and how to integrate such research with research done on level I. Once the different types of literature are integrated and appropriate empirical data are collected, this could trickle down in reverse order from our paper, from research into new, better integrated theories, into more innovative pedagogical tools and, hopefully, into the development of a multidisciplinary consulting approach to negotiation. We believe that consulting in negotiation requires not only knowledge of negotiation, but also knowledge of the different fields of organizational design and operation. Our topic could therefore contribute to bringing negotiation closer to other disciplines, clearly to "pop the bubble" in which most of the negotiation research now stands. For example, the knowledge management literature may be beneficial in investigating the processes that allow trained individuals in negotiation to bring back their knowledge to their organization, or how organizations could implement negotiation knowledge management systems.

Beyond the research aspects, we would like to circle back to the practical issue: we insist that there seems to be a demand for knowledge on this subject. After all, the levers one can use to advance an organization are getting rarer by the day. Managers need to achieve better financial performance, while also taking into consideration other elements, such as the employees' wellbeing, the environment, and an ever-changing legal context. These complex factors create new avenues for negotiations within the organization and hence more demand for skills on the issue. But, as we have shown, skills are not enough. The organization also needs to reinvent itself to be effective at negotiating, and, as educators, researchers and theorists, it is our role to develop the tools to reach such an objective.

\section{References}


Ackermann, F., \& Eden, C. (2011). Negotiation in Strategy Making Teams: Group Support Systems and the Process of Cognitive Change. Group Decision and Negotiation, 20(3), 293-314. https://doi.org/10.1007/s10726-008-9133-y

Amason, A. C. (1996). Distinguishing the effects of functional and dysfunctional conflict on strategic decision making: Resolving a paradox for top management teams. Academy of Management Journal, 39(1), 123-148.

Amason, A. C., \& Schweiger, D. M. (1997). The Effects of Conflict on Strategic Decision Making Effectiveness and Organizational. Using Conflict in Organizations, 101.

Anderson, C. R., \& Zeithaml, C. P. (1984). Stage of the product life cycle, business strategy, and business performance. Academy of Management Journal, 27(1), 5-24.

Appelt, K. C., \& Higgins, E. T. (2010). My way: How strategic preferences vary by negotiator role and regulatory focus. Journal of Experimental Social Psychology, 46(6), $1138-1142$.

Behfar, K., Friedman, R., \& Brett, J. (2016). Managing co-occurring conflicts in teams. Group Decision and Negotiation, 25(3), 501-536.

Borbély, A. (2011). Agency in Conflict Resolution as a Manager-Lawyer Issue: Theory and Implications for Research. Negotiation and Conflict Management Research, 4(2), 129144. https://doi.org/10.1111/j.1750-4716.2011.00076.x

Borbély, A. (2014). Negotiations, Ryanair-Style. The Case Center, Ref. no. 3.

Bottom, W. P., \& Studt, A. (1993). Framing effects and the distributive aspect of integrative bargaining. Organizational Behavior and Human Decision Processes, 56(3), 459. Retrieved from http://proxygw.wrlc.org/login?url=http://search.proquest.com/docview/223183348?acco untid $=11243$

Bradbury-Huang, H. (2010). What is good action research? Why the resurgent interest? 
Action Research.

Brouthers, K., \& Bamossy, G. (1997). The role of key stakeholders in international joint venture negotiations: Case studies from Eastern Europe. Journal of International Business Studies, 28(2), 285-308. Retrieved from http://proxygw.wrlc.org/login?url=http://search.proquest.com/docview/197157064?acco untid $=11243$

Brydon-Miller, M., Greenwood, D., \& Maguire, P. (2003). Why action research? Action Research.

Cai, Y., Jo, H., \& Pan, C. (2012). Doing well while doing bad? CSR in controversial industry sectors. Journal of Business Ethics.

Caputo, A. (2013). A Literature Review of Cognitive Biases in Negotiation Processes. International Journal of Conflict Management, 24(4), 274-398. https://doi.org/10.1108/IJCMA-08-2012-0064

Caputo, A. (2016). Overcoming judgmental biases in negotiations: A scenario-based survey analysis on third party direct intervention. Journal of Business Research, 69(10), 43044312. https://doi.org/http://dx.doi.org/10.1016/j.jbusres.2016.04.004

Clark, N. (2014). Air France, after strikes, faces new uncertainty. The New York Times. New York.

Collis, D. J. (1994). Research note: how valuable are organizational capabilities? Strategic Management Journal, 15(S1), 143-152.

Costa, P. L., Passos, A. M., \& Bakker, A. B. (2015). Direct and Contextual Influence of Team Conflict on Team Resources, Team Work Engagement, and Team Performance. Negotiation and Conflict Management Research, 8(4), 211-227. https://doi.org/10.1111/ncmr.12061

Crump, L. (2010). Strategically managing negotiation linkage dynamics. Negotiation and 
Conflict Management Research, 3(1), 3-27.

Dierickx, I., \& Koza, M. (1991). Information Asymmetries - How Not to "Buy a Lemon" in Negotiating Mergers and Acquisitions. European Management Journal, 9(3), 229.

Retrieved from

http://proxygw.wrlc.org/login?url=http://search.proquest.com/docview/213801027?acco untid $=11243$

Donaldson, T., \& Preston, L. E. (1995). The stakeholder theory of the corporation: Concepts, evidence, and implications. Academy of Management Review, 20(1), 65-91.

Dörrenbächer, C., \& Gammelgaard, J. (2006). Subsidiary role development: The effect of micro-political headquarters-subsidiary negotiations on the product, market and valueadded scope of foreign-owned subsidiaries. Journal of International Management, 12(3), 266-283.

Dye, R., \& Sibony, O. (2007). How to improve strategic planning. McKinsey Quarterly, 3, 40.

Eisenhardt, K. M., \& Martin, J. A. (2000). Dynamic capabilities: what are they? Strategic Management Journal, 21(10-11), 1105-1121. https://doi.org/10.1002/10970266(200010/11)21:10/11<1105::AID-SMJ133>3.0.CO;2-E

Elbanna, S., Ali, A. J., \& Dayan, M. (2011). Conflict in strategic decision making: do the setting and environment matter? International Journal of Conflict Management, 22(3), 278-299.

ElShenawy, E. (2010). Does negotiation training improve negotiators' performance? Journal of European Industrial Training, 34(3), 192-210. https://doi.org/10.1108/03090591011031719

Ertel, D. (1999). Turning negotiation into a corporate capability. Harvard Business Review, $77,55-71$.

Fisher, R. J., Ury, W., \& Patton, B. M. (1981). Getting to Yes: Negotiating Agreement without 
Giving In. Boston: Houghton-Mifflin.

Freeman, R. E. (2010). Strategic management: A stakeholder approach. Cambridge University Press.

Grant, R. M. (2010). Contemporary strategy analysis and cases: text and cases. John Wiley \& Sons.

Greenhalgh, L., \& Lewicki, R. J. (2015). Evolution of Teaching Negotiation: The Legacy of Walton and McKersie. Negotiation Journal, 31(4), 465-476.

Helfen, M., \& Sydow, J. (2013). Negotiating as institutional work: The case of labour standards and international framework agreements. Organization Studies, 34(8), 10731098.

Helms, W. S., Oliver, C., \& Webb, K. (2012). Antecedents of Settlement on a New Institutional Practice: Negotiation of the Iso 26000 Standard on Social Responsibility. Academy of Management Journal, 55(5), 1120-1145.

https://doi.org/10.5465/amj.2010.1045

Hitt, M. A., Biermant, L., Shimizu, K., \& Kochhar, R. (2001). Direct and moderating effects of human capital on strategy and performance in professional service firms: A resourcebased perspective. Academy of Management Journal, 44(1), 13-28.

Jemison, D. B., \& Sitkin, S. B. (1986). Corporate acquisitions: A process perspective. Academy of Management Review, 11(1), 145-163.

Johnston, M., \& Marshall, G. (2016). Sales force management: Leadership, innovation, technology.

Kauer, D., Tanja, C. P. zu W., \& Utz, S. (2007). Effects of top management team characteristics on strategic decision making. Management Decision, 45(6), 942. https://doi.org/http://dx.doi.org/10.1108/00251740710762017

Kim, W. C. (1988). The effects of competition and corporate political responsiveness on 
multinational bargaining power. Strategic Management Journal, 9(3), 289-295.

Kopelman, S. (2014). Negotiating genuinely: Being yourself in business.

Lax, D. A., \& Sebenius, J. K. (1986). The Manager as Negotiator: Bargaining for Cooperation and Competitive Gain. New York: Macmillan.

Lax, D. A., \& Sebenius, J. K. (2006). 3-D negotiation: Powerful tools to change the game in your most important deals. Harvard Business Press.

Lee, J.-R., Chen, W.-R., \& Kao, C. (1998). Bargaining power and the trade-off between the ownership and control of international joint ventures in China. Journal of International Management, 4(4), 353-385.

Lewicki, R. J., Saunders, D., \& Barry, B. (2014). Negotiation (7th ed.). New York: McGraw Hill.

Lippman, S. A., \& Rumelt, R. P. (2003). A bargaining perspective on resource advantage. Strategic Management Journal, 24(11), 1069-1086.

Luo, Y. (1999). Toward a conceptual framework of international joint venture negotiations. Journal of International Management, 5(2), 141-165.

Luo, Y., \& Shenkar, O. (2002). An empirical inquiry of negotiation effects in cross-cultural joint ventures. Journal of International Management, 8(2), 141-162. Retrieved from http://search.ebscohost.com/login.aspx $?$ direct $=$ true $\& d b=$ eoah $\& A N=3755085 \&$ site $=$ ehost -live\&scope $=$ site

Mintzberg, H. (1978). Patterns in strategy formation. Management Science, 24(9), 934-948.

Mintzberg, H. (1987). The strategy concept I: Five Ps for strategy. California Management Review, 30(1), 11-24.

Mintzberg, H., Ahlstrand, B., \& Lampel, J. (1998). Strategy Safari (Vol. 2). New York: Free Press.

Mnookin, R. H., \& Susskind, L. E. (1999). Negotiating on behalf of others: advice to lawyers, 
business executives, sports agents, diplomats, politicians, and everybody else (Vol. 1). Sage Publications.

Moatti, V., Ren, C. R., Anand, J., \& Dussauge, P. (2014). Disentangling the performance effects of efficiency and bargaining power in horizontal growth strategies: An empirical investigation in the global retail industry. Strategic Management Journal, 36(5), 745757. https://doi.org/10.1002/smj.2244

Movius, H. (2008). The effectiveness of negotiation training: On teaching. Negotiation Journal, 24(4), 509-531. https://doi.org/10.1111/j.1571-9979.2008.00201.x

Movius, H., \& Susskind, L. (2009). Built to Win: Creating A World Class Negotiating Organization. Boston: Harvard Business Press.

Munduate, L., Euwema, M., \& Elgoibar, P. (2012). Ten Steps for Empowering Employee Representatives in the New European Industrial Relations: New European Industrial Relations NEIRE Handbook. BOOK, McGraw Hill.

Olekalns, M., \& Adair, W. L. (2013). Handbook of Research on Negotiation. Cheltenham, UK: Edward Elgar Publishing.

Pahl, J. M., \& Roth, K. (1993). Managing the headquarters-foreign subsidiary relationship: the roles of strategy, conflict, and integration. International Journal of Conflict Management, 4(2), 139-165.

Parayitam, S., \& Dooley, R. S. (2011). Is too much cognitive conflict in strategic decisionmaking teams too bad? International Journal of Conflict Management, 22(4), 342-357.

Porter, M. E. (1979). How Competitive Forces Shape Strategy. Harvard Business Review, 137-145. https://doi.org/10.1097/00006534-199804050-00042

Porter, M. E. (1980). Competitive Strategy. New York: Free Press.

Porter, M. E. (2008). The Five Competitive Forcs That Shape Strategy. Harvard Business Review, 86(1), 78-93. 
Quélin, B., \& Duhamel, F. (2003). Bringing together strategic outsourcing and corporate strategy:: Outsourcing motives and risks. European Management Journal, 21(5), 647661.

Raiffa, H. (1982). The Art and Science of Negotiation. Cambridge (MA): Harvard University Press.

Rink, D. R., \& Swan, J. E. (1979). Product life cycle research: A literature review. Journal of Business Research, 7(3), 219-242.

Sengupta, S., Krapfel, R., \& Pusateri, M. (1997). The Strategic Sales Force. Marketing Management, 29-34. Retrieved from http://search.proquest.com.ezproxy.napier.ac.uk/docview/194193043/72958600477449E FPQ/8?accountid=16607

Sharma, A. (1997). Professional as agent: Knowledge asymmetry in agency exchange. Academy of Management Review, 22(3), 758-798.

Sharma, S., Bottom, W. P., \& Elfenbein, H. A. (2013). On the role of personality, cognitive ability, and emotional intelligence in predicting negotiation outcomes A meta-analysis. Organizational Psychology Review, 3(4), 293-336.

Simonin, B. L. (1999). Ambiguity and the process of knowledge transfer in strategic alliances. Strategic Management Journal, 20(7), 595-623.

Stimec, A. (2014). Vers une ingénierie des négociations dans les organisations. Recherches En Sciences de Gestion, 102(3), 195-212.

Sydow, J., Schreyögg, G., \& Koch, J. (2009). Organizational path dependence: Opening the black box. Academy of Management Review, 34(4), 689-709.

Teece, D. J. (2007). Explicating dynamic capabilities: the nature and microfoundations of (sustainable) enterprise performance. Strategic Management Journal, 28(13), 13191350. 
Teece, D. J., Pisano, G., \& Shuen, A. (1997). Dynamic capabilities and strategic management. Strategic Management Journal, 18(7), 509-533.

Thompson, L. L., Wang, J., \& Gunia, B. C. (2010). Negotiation. Annual Review of Psychology, 61, 491-515.

Thompson, L., \& Loewenstein, G. (1992). Egocentric Interpretations of Fairness and Interpersonal Conflict. Organizational Behavior and Human Decision Processes, 51(2), 176-197. Retrieved from http://proxygw.wrlc.org/login?url=http://search.proquest.com/docview/223189247?acco untid $=11243$

Walsh, J. P. (1989). Doing a deal: Merger and acquisition negotiations and their impact upon target company top management turnover. Strategic Management Journal, 10(4), 307322.

Walsh, J. P., \& Fahey, L. (1986). The role of negotiated belief structures in strategy making. Journal of Management, 12(3), 325-338.

Walton, R. E., \& McKersie, R. B. (1965). A Behavioral Theory of Labor Negotiations. Beverly Hills, CA: Sage Publications.

Wang, Y., \& Rajagopalan, N. (2015). Alliance Capabilities Review and Research Agenda. Journal of Management, 41(1), 236-260.

Weiss, S. E. (1990). The long path to the IBM-Mexico agreement: an analysis of the microcomputer investment negotiations, 1983-86. Journal of International Business Studies, 565-596.

Welbourne, T. M., \& Pardo-del-Val, M. (2009). Relational capital: strategic advantage for small and medium-size enterprises (SMEs) through negotiation and collaboration. Group Decision and Negotiation, 18(5), 483-497.

Wernerfelt, B. (1984). A resource-based view of the firm. Strategic Management Journal, 
5(2), 171-180.

Winter, S. G. (2003). Understanding dynamic capabilities. Strategic Management Journal, 24(10), 991-995.

Yan, A., \& Gray, B. (2001). Antecedents and Effects of Parent Control in International Joint Ventures. Journal of Management Studies, 38(3), 393-416. Retrieved from http://search.ebscohost.com/login.aspx?direct=true $\& \mathrm{db}=$ eoah $\& A N=9301317 \&$ site $=$ ehost -live\&scope $=$ site

Zartman, I. W. (1977). Negotiation as a Joint Decision-Making Process. Journal of Conflict Resolution, 21(4), 619-638.

Zartman, I. W. (1988). Common elements in the analysis of the negotiation process. Negotiation Journal, 4(1), 31-43. 
Table 1 - Summary of the model

\begin{tabular}{|c|c|c|c|c|c|}
\hline Levels & Objective & Main question & Focal point & Negotiation seen as & Possible variables \\
\hline $\begin{array}{l}\text { Level I- } \\
\text { Individual }\end{array}$ & $\begin{array}{l}\text { Study and development } \\
\text { of negotiation from an } \\
\text { individual perspective }\end{array}$ & $\begin{array}{l}\text { How people interact at a } \\
\text { single negotiation table }\end{array}$ & $\begin{array}{l}\text { Negotiators' skills and } \\
\text { personality }\end{array}$ & Individual event & $\begin{array}{l}\text { Negotiation } \\
\text { characteristics, } \\
\text { performance, processes } \\
\text { and outcomes, } \\
\text { satisfaction, ethics }\end{array}$ \\
\hline $\begin{array}{l}\text { Level II- } \\
\text { Linkages }\end{array}$ & $\begin{array}{l}\text { Study and development } \\
\text { of the system of } \\
\text { negotiations within an } \\
\text { organization }\end{array}$ & $\begin{array}{l}\text { How different } \\
\text { negotiations impact one } \\
\text { another }\end{array}$ & $\begin{array}{l}\text { Negotiations as the } \\
\text { context for another } \\
\text { negotiation (e.g. path } \\
\text { dependency) }\end{array}$ & $\begin{array}{l}\text { System of longitudinal } \\
\text { events }\end{array}$ & $\begin{array}{l}\text { History, context, } \\
\text { situational awareness, } \\
\text { knowledge / experience } \\
\text { sharing }\end{array}$ \\
\hline $\begin{array}{l}\text { Level III- } \\
\text { Infrastructure }\end{array}$ & $\begin{array}{l}\text { Study and development } \\
\text { of the organizational } \\
\text { infrastructure in support } \\
\text { of negotiations }\end{array}$ & $\begin{array}{l}\text { How an organization } \\
\text { may organize its } \\
\text { negotiation functions to } \\
\text { be more efficient }\end{array}$ & $\begin{array}{l}\text { The organization's } \\
\text { management of } \\
\text { negotiations }\end{array}$ & $\begin{array}{l}\text { Organizational issue / } \\
\text { knowledge } \\
\text { management system }\end{array}$ & $\begin{array}{l}\text { Infrastructure } \\
\text { characteristics, } \\
\text { management practices, } \\
\text { incentive systems, } \\
\text { KPIs, knowledge } \\
\text { transfer }\end{array}$ \\
\hline $\begin{array}{l}\text { Level IV- } \\
\text { Capability }\end{array}$ & $\begin{array}{l}\text { Study and development } \\
\text { of negotiations as a } \\
\text { strategic resource }\end{array}$ & $\begin{array}{l}\text { How negotiation (taken } \\
\text { as a whole) can be the } \\
\text { source of competitive } \\
\text { advantage }\end{array}$ & $\begin{array}{l}\text { Top management's } \\
\text { consideration for } \\
\text { negotiation and } \\
\text { negotiations' impact on } \\
\text { competitive advantage }\end{array}$ & $\begin{array}{l}\text { Top management } \\
\text { decision making issue / } \\
\text { organizational culture }\end{array}$ & $\begin{array}{l}\text { Organizational } \\
\text { performance, top } \\
\text { management } \\
\text { commitment, } \\
\text { idiosyncrasies among } \\
\text { organizations }\end{array}$ \\
\hline
\end{tabular}

